\title{
Groundwater Modelling to Predict Management Options for Vavuniya Region Aquifer
}

\author{
S.Shanmuhananthan, Nimal P.D.Gamage and D.C.H.Senarath
}

\begin{abstract}
The problems in sustainable groundwater management are of major and vital importance in the areas that comprise shallowly weathered and rarely fractured rocks with thin soil mantle, as recharge and yield are relatively low in these areas due to low porosity and permeability. In order to find out better ways and means to evaluate, develop and manage groundwater resources in these regions, an attempt was made to understand the groundwater system of Vavuniya region aquifer through numerical modelling and to examine the behaviour of the aquifer under various operating conditions. The results reveal that the groundwater usage has already reached its optimum level in this region and immediate action is required not only to control further expansion of groundwater exploitation but also to regulate groundwater withdrawal especially in low rainfall years. Further, the influences of the river and subsurface dams in groundwater system were examined and the results show that the non-perennial river has less influences and the subsurface dams certainly have an impact on groundwater system but this has to be studied further in detail, in order to minimize the negative impact and utilize the merits.
\end{abstract}

Keywords: groundwater, aquifer, modelling, Vavuniya

\section{Introduction}

The Vavuniya region aquifer is an unconfined overburden aquifer. This aquifer comprises a thin soil mantle of an average thickness of $3 \mathrm{~m}$ and a regolith of $10 \mathrm{~m}$ over a rarely fractured rock base. Due to the low porosity and permeability, the hydraulic conductivity and specific yield of this aquifer are relatively low. Therefore the problems in sustainable groundwater management are of major and vital importance in this area.

The four-year observation well records since 1999 reveal that there is a substantial decline in the groundwater table in this region. Figure 1 clearly illustrates that the groundwater table did not reach its previous year maximum level during this period.

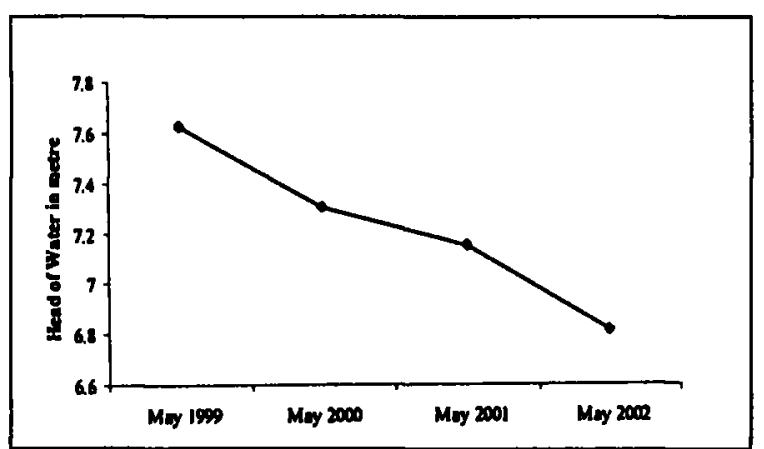

Figure 1 Maximum Groundwater level at the end of recharging period.
This may be due to the excessive exploitation of ground water or due to the reduction in recharge of aquifer or the combination of both.

The intention of this research is to examine the behaviour of groundwater flow in this aquifer and come out with an appropriate strategy to ensure sustainability in groundwater management for this region.

The specific objectives are,

- to achieve an understanding of the basic mechanisms that govern the flow in the aquifer through numerical modelling.

- to prepare a water balance of the territory.

- to examine the influence of river and Subsurface Dams in the groundwater system. 


\section{Study site}

\subsection{Location}

The upper river basin of a tributary of Parankiaru in Vavuniya District was selected for this study. The study area is located at the Northern part of Sri Lanka between latitudes $9^{\circ}$ $22^{\prime}$ and $9^{\circ} 52^{\prime}$ North and longitudes $79^{\circ} 52^{\prime}$ and $80^{\circ} 49^{\prime}$ East. The catchment's slope is $0.3 \%-0.4 \%$.

The extent of the study area is $177.8 \mathrm{sq} . \mathrm{km}$. Agriculture land and rangeland cover $70 \%$ of the total extent and $20 \%$ of the land is covered by forest. The remaining $10 \%$ is occupied by wetlands and built up lands.

The agricultural land area falling within the study area is about 4,860 hectares of which 2,700 hectares are irrigated by 7 medium and 118 minor Irrigation Schemes.

\subsubsection{Sources of data}

Geology and aquifer physical parameters such as geological data, aquifer type and aquifer thickness details were collected from the driller's logs obtained from the Water Resources Board, from the textbook by Cooray (1967) and from the Geology and soil maps published by the Survey Department.

The topographical data of the study area was collected from the $1^{\prime \prime}=1$ mile, $2^{\prime \prime}=1$ mile toposheets published by the Survey Department.

The possible range for the Hydraulic conductivity and Specific yield of the aquifer were determined based on the pumping data obtained from the well test conducted by the Water Resources Board.

Land usage details were collected from the Vavuniya district land use map prepared by the Survey Department and from the Statistical Handbook of Vavuniya District published by the District Secretary.

A 4-year seasonal water levels of 12 observation wells were obtained from Eng.S.S.Sivakumar, who is a PhD candidate, doing his research in the field of groundwater.

Daily rainfall data for the period from 1st October 1998 to 30th September 2002 and Evapotranspiration data were collected from the Irrigation Department Land Metrological Department records.
Root Constant values were obtained from the North - West Land \& Water Resources Development Project Report (1981).

Details of Medium \& Minor Irrigation Schemes were collected from the Irrigation Department's records and. Agrarian Development Department's records.

Groundwater extraction related data such as human population, livestock population, domestic water supply details, O.F.C cultivation area, vegetable and fruit cultivation area and number of wells were collected from the Statistical Handbook of Vavuniya District and Water Supply \& Drainage Board records.

\subsection{Aquifer Properties}

Considering the importance of having a fairly accurate range of aquifer properties such as hydraulic conductivity and specific yield for this study, a well test at an existing open dug well was conducted with assistance from the Water Resources Board. The data collected from this test was analyzed using Boulton - Streltsova's curve fitting method which is the most appropriate method for a large diameter open dug well in an unconfined aquifer as it takes into account the storage capacity of the well itself. The test results for the Hydraulic Conductivity and Specific Yield are $2.4 \mathrm{~m} /$ day and $3.4 \%$ respectively.

Based on there test results and the results of the pumping test carried out by De Silva (1995) in the adjoining district of Anuradhapura, where the aquifer is very similar to that of the study area, suitable ranges of values for hydraulic conductivity (5 - $25 \mathrm{ft} /$ day) and specific yield $(3 \%-8 \%)$ were assumed for the modelling.

\subsection{Zone division}

Because recharge is a non - linear process, it is not possible to use average values of each controlling factor to derive an average recharge. Recharge should be estimated separately for each homogeneous zone; the spatially varying values are of course essential for groundwater modelling studies. (Lerner, 1990). For the scope of this study, the total project area falling within the 3 Agrarian Service Centre Divisions and 26 Grama Niladhari Divisions are clustered into 8 Zones as shown in Fig4. 


\subsection{Land usage}

The land usage pattern plays a vital role in determining recharge and withdrawal of groundwater from the aquifer. Especially the type of vegetation cover decides the rate of actual evaporation depending on its root constant and that ultimately decides the rate of recharge.

Further percolation from irrigated lands contributes to the recharge of aquifer significantly. To simplify the computation without affecting the required accuracy of this study, 14 different types of lands were identified in the project area and clustered into 4 grades.

\subsection{Water-table fluctuations}

The main rainy season extends from early October to late January and sub rainy season extends from March to late May. The aquifer in this region gets recharged during October to January and then March to May.

The average annual rainfall of the district is around $1400 \mathrm{~mm}$. From June onwards the groundwater table drops and in September the water level reaches its minimum. Hence, the recharging season prevails 8 months from October and discharging season prevails 4 months from June.

\subsection{Root Constant}

The degree to which potential and actual evaporation rates diverge is a function of soil and vegetation characteristics and is explained by Penman (1949) in terms of a "root constant"; this is a measure of the amount of water readily available within the root range, expressed as an equivalent rainfall (Rushton and Ward, 1979).

As each zone has agricultural, forest and wetlands in different proportions, the weighted root constant for each zone was computed separately and a sensitivity analysis was carried out to examine the sensitivity to the root constant. The sensitivity analysis showed that the root constant is not that sensitive in these studies and it would not affect the recharge value for its selected range.

\subsection{Rainfall recharge}

According to the Penman - Grindley model (Penman 1950; Grindley 1967, 1969) the evapotranspiration takes place at its potential rate only if the soil moisture deficit is within the root constant. If the soil moisture deficit exceeds the root constant but within the upper limit of root constant, then only $10 \%$ of the potential evapotranspiration takes place. Beyond that, no evapotranspiration takes place. The recharge takes place only if there is no soil moisture deficit. This concept is used in the calculation of daily actual evapotranspiration and daily net rainfall recharge.

\subsection{Irrigation Recharge}

The Irrigation schemes contribute to recharge of ground water through,

\section{(i) Storage losses from reservoirs \\ (ii) Irrigation losses from channels \\ (iii) Irrigation losses from fields}

Though there are many methods available for more accurate prediction of these losses, they demand more field details, which are not available in the field in most cases. In such circumstances the researchers are compelled to assume more data which may not be correct and that leads to inaccurate estimations.

Therefore, one of the intentions of this study is to find appropriate methods, which require the data that is normally available, or is easy to collect from the field.

The operation study which deals with the reservoir water balance is a regular practice that is being carried out by the Irrigation Department to asses the water availability on a monthly basis. The estimation of percolation losses from the reservoir and irrigation losses from Channels and fields are some of the important steps involved in operation study.

The estimation of these losses using Ponrajah (1984) method is applied to many irrigation schemes in the region by the Irrigation Department for several years and the results are proven to be very satisfactory.

Therefore, the methods described by Ponrajah (1984) are used in this study. The basic concepts of these methods are as follows.

2.8.1 Recharge due to storage losses from
reservoirs.

According to Ponrajah (1984), the seepage losses from reservoirs are directly proportional to the 
volume of water stored in the reservoir. Therefore, the recharge from tank storage per day can be expressed by the following equation.

$\mathrm{Rts}=\mathrm{C}_{3} \times \mathrm{V} / \mathrm{N}$

where, Rts is the recharge from tank storage per day, $\mathrm{V}$ is the average monthly tank storage, $\mathrm{N}$ is the number of days in the calendar month and $\mathrm{C}_{3}$ is the Storage Recharge Factor. The storage recharge factor $\mathrm{C}_{3}$ was found as a by-product from the calibration of runoff against reservoir daily water balance. The value of $C_{3}$ found from calibration is $\mathbf{0 . 0 1 5}$.

\subsubsection{Recharge due to irrigation losses from channels}

According to Ponrajah (1984), conveyance losses can be expressed by the following equations.

$\mathrm{C.L}=(1-\mathrm{Ec}) \times(\mathrm{ETC}-\mathrm{PxEa}) / \mathrm{Ea} / \mathrm{Ec} \ldots \ldots \ldots .$.
$\mathrm{ETC}=\mathrm{ETo} \times \mathrm{Kc}$

where, ETo is the reference crop evapotranspiration, ETc is the crop water requirement, $\mathrm{P}$ is the precipitation, $\mathrm{Ea}$ is the application efficiency, Ec is the conveyance efficiency and $\mathrm{Kc}$ is the crop factor.

Average values of $60 \%$ and $65 \%$ were assumed for Ea and Ec considering the field conditions and records available in the Irrigation department. The values of $\mathrm{Kc}$ recommended for different growth stages of paddy were adopted appropriately.

Conveyance losses are due to Seepage, Deep percolation and Evaporation. The deep percolation losses contribute to groundwater recharge. The magnitude of deep percolation from channels is equal to conveyance losses multiplied by a factor $C_{1}$. where, $C_{1}$ is the channel losses recharge coefficient $\left(0<C_{1}<1\right)$.

\subsubsection{Recharge due to irrigation losses from fields}

According to Ponrajah (1984), Farm losses can be expressed by the following equation.

$F . L=(1-E a) \times(E T c-P \times E a) / E a$

$\mathrm{ETc}=\mathrm{ETo} \times \mathrm{Kc}$

where, ETo is the reference crop evapotranspiration, ETc is the crop water requirement, $\mathrm{P}$ is the precipitation, $\mathrm{Ea}$ is the application efficiency, Ec is the conveyance efficiency and $\mathrm{Kc}$ is the crop factor.

Average values of $60 \%$ and $65 \%$ were assumed for Ea and Ec considering the field conditions and records available in the Irrigation department. The values of $\mathrm{Kc}$ recommended for different growth stages of paddy were adopted appropriately.

Farm losses are due to Surface runoff, Deep percolation and Leakage. Deep percolation losses contribute to groundwater recharge. Deep percolation from fields is equal to farm losses multiplied by a factor $C_{2}$, where, $C_{2}$ is the farm losses recharge coefficient $\left(0<C_{2}<1\right)$.

\subsection{River Recharge}

The tributary of Parankiaru, which passes through the domain, is a typical rain fed stream and has two branches. All 7 medium Irrigation Schemes in the domain are sited in these branches. Water flows in these streams, only during the- recharging period. MODFLOW (Prudic, 1988), which computes river leakage using Darcy's Law is employed in this calculation.

\subsection{Groundwater withdrawals}

The seasonal basic details required for the computation of Groundwater withdrawal are collected for each Grama Niladhari Division. Using this basic data, Groundwater withdrawal for each season was calculated separately for each zone.

\section{Conceptual model}

The U.S.Geological Survey's (USGS) MODFLOW three - dimensional, groundwater flow model, which was introduced in 1984 as a versatile simulator of groundwater flow within an aquifer (Prudic, 1988), was selected for this study.

MODFLOW can simulate steady state or transient flow; unconfined, confined, and leakyconfined conditions; spatial variations in hydraulic parameters; discharge to or from streams; pumping or injection from wells; and specified-head, specified-flux, and head dependent - flux boundary conditions. The block - cantered formation places a point, called 
a node, at the center of the cell, where the hydraulic conductivities are assumed to be uniform over the extent of a cell.

Based on these assumptions, the model calculates coefficients, called conductance, that are multiplied by head difference to determine flow between cells. (Reilly and Harbaugh, 1993)

\subsection{Zero flow boundary condition}

According to Boonstra and Ridder (1981), a groundwater divide, by definition, is a zero flow boundary as no flow occurs across the streamline running over the top of the divide. Accordingly the ridge of the groundwater head equipotential contours was considered as noflow boundary.

\subsection{River Boundary Condition}

MODFLOW's River Package (RIV) allows incorporating surface water boundary conditions into a groundwater flow model. Rivers and streams contribute to or drain from the groundwater system depending on the head gradient between the surface water body and the groundwater regime.

\subsection{Constant Head Boundary Condition}

For the scope of this study, Constant Head Boundary Condition was used only for the steady state simulations.

\subsection{Recharge Boundary Condition}

Groundwater recharge is accommodated by MODFLOW through the Recharge Package (RCH). The recharge package is designed to simulate aerial distributed recharge to the groundwater system.

The values of seasonal recharge for each zone by various recharge components are computed and converted into aerial distributed recharge and assigned to the respective zones. The effect of evaporation and evapotranspiration has already been already taken into account while computing recharge values and hence there is no need to input them into the model separately.

\subsection{Ground water withdrawal}

The values of seasonal withdrawals for each zone by various withdrawal components are computed and converted into pumping rates and assigned to the pumps of the respective zones.

\subsection{Time Steps}

The Duration of all transient state groundwater flow covers 7 Seasons starting from 1st of June 1999. Out of these data sets available for all seven seasons, the first five were used for calibration and the rest two were used for verification. The duration is not relevant for the steady state simulations. The details of stress periods covered by the transient state groundwater flow simulation runs are illustrated in Table 1.

\subsection{Setting Initial Conditions}

The steady - state groundwater flow is a boundary value problem only. But transient state groundwater flow is a boundary value as well as an initial value problem. Since the scope of this study covers more than two seasons, the groundwater flow in this aquifer is essentially a transient - state flow as the rate of recharge and rate of extraction varies with time. Therefore, this model has to be simulated in the transient state condition. But initial heads have to be fed into the model in order to run the model in the transient - state condition. These initial heads, which should match with the observed values, are generated by a steady state simulation under hypothetical conditions and transferred into the transient model. Therefore, the only purpose of steady state simulation in this study is to generate initial heads for the transient state simulation.

\section{Model predictions}

The following simulation runs were carried out.

\subsection{R1 - Steady state flow simulation}

Hypothetical Constant Heads boundary conditions were imposed in the periphery of the domain and the river boundary conditions were imposed within the domain. These conditions were adjusted by trial and error so that the head equipotential contours generated by the simulation run matches with the observed head equipotential contours of the 1st season. Neither recharge nor withdrawal of groundwater was considered in this simulation. 


\subsection{R2 - Steady state flow simulation}

The purpose of this simulation is to improve the heads generated by the simulation R1 at the observation well locations to match almost exactly with the observed values. The error in initial heads at the points of Observation Wells will affect the results of the transient simulation very much. Therefore, to generate heads at observation well locations almost equal to the observed values, constant head boundary conditions were imposed at well points. The other conditions remain the same as the simulation R1. The matching between the observed and predicted head equipotential contours is found to be fairly satisfactory. No verification was done for $\mathrm{R} 1$ and $\mathrm{R} 2$, as none of the variable parameters was calibrated in these simulations. The groundwater flow pattern of these two simulations was examined by assigning some forward tracking particles in the domain.

The graphical representation of the results is given in Figure 2. The results reveal that the groundwater flow direction is almost parallel to surface runoff under Steady State condition.

\subsection{R3 - Transient state flow simulation}

No constant head boundary conditions were imposed. Only river boundary conditions were imposed. Initial heads were imported from model Run R2. In this simulation the values of hydraulic conductivity and specific yield were optimized. The modelling results reveal that the Hydraulic Conductivity and Specific Yield values for 8 zones are in the ranges of $4-7 \mathrm{~m} /$ day and $5-7 \%$ respectively.

These values are slightly higher than the pumping test results. This may be due to the degree of accuracy of the method adopted to analyze the pumping test data or the degree to which the subsurface conditions complied with the assumptions or the combination of both.

\subsection{R4 - Transient state flow simulation}

Initial and boundary conditions were the same as R3. The optimized values of Hydraulic Conductivity and Specific Yield obtained from R3 were used in this simulation. Channel recharge coefficient and Field recharge

Table 1 - The details of stress periods

\begin{tabular}{|c|l|l|c|c|c|c|}
\hline $\begin{array}{c}\text { Stress Period } \\
\text { No }\end{array}$ & Stress Period & Season & $\begin{array}{c}\text { Start Time } \\
\text { (days) }\end{array}$ & $\begin{array}{c}\text { End time } \\
\text { (days) }\end{array}$ & $\begin{array}{c}\text { Time Step } \\
\text { (days) }\end{array}$ & Multiplier \\
\hline 01. & June 99 - Sept 99 & Discharge & 0 & 120 & 10 & 1.2 \\
02. & Oct 99 - May 00 & Recharge & 120 & 365 & 10 & 1.2 \\
03. & June 00 - Sept 00 & Discharge & 365 & 485 & 10 & 1.2 \\
04. & Oct 00 - May 01 & Recharge & 485 & 730 & 10 & 1.2 \\
05. & June 01 - Sept 01 & Discharge & 730 & 850 & 10 & 1.2 \\
06. & Oct 01 - May 02 & Recharge & 850 & 1095 & 10 & 1.2 \\
07. & June 02 - Sept 02 & Discharge & 1095 & 1215 & 10 & 1.2 \\
\hline
\end{tabular}

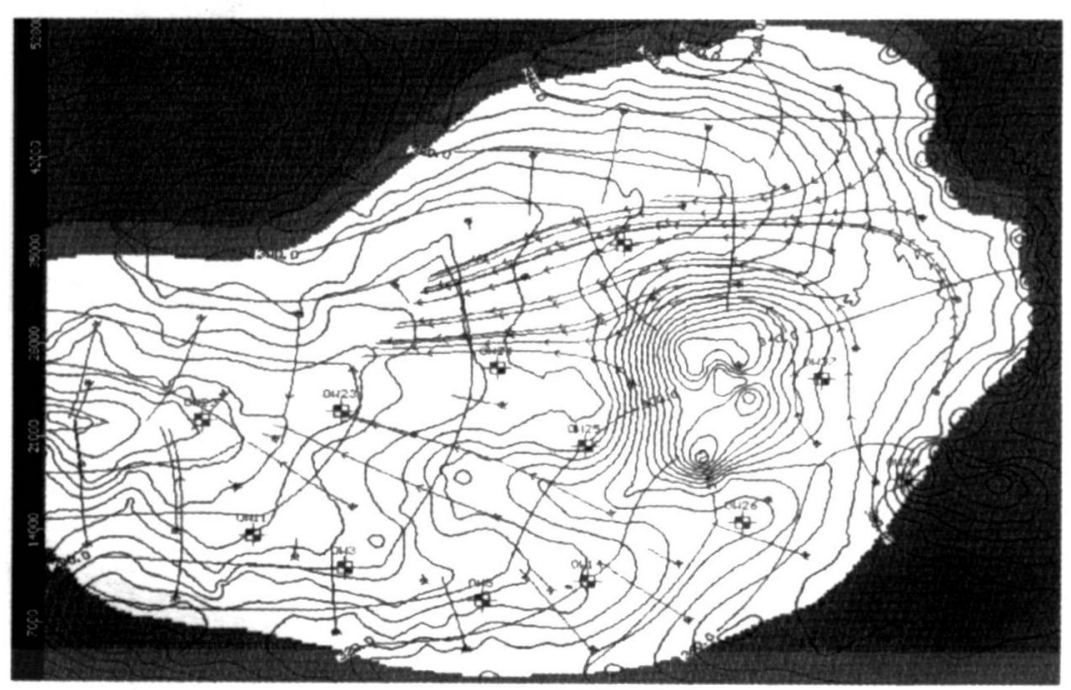

Figure 2 The graphical representation of groundwater flow pattern. 


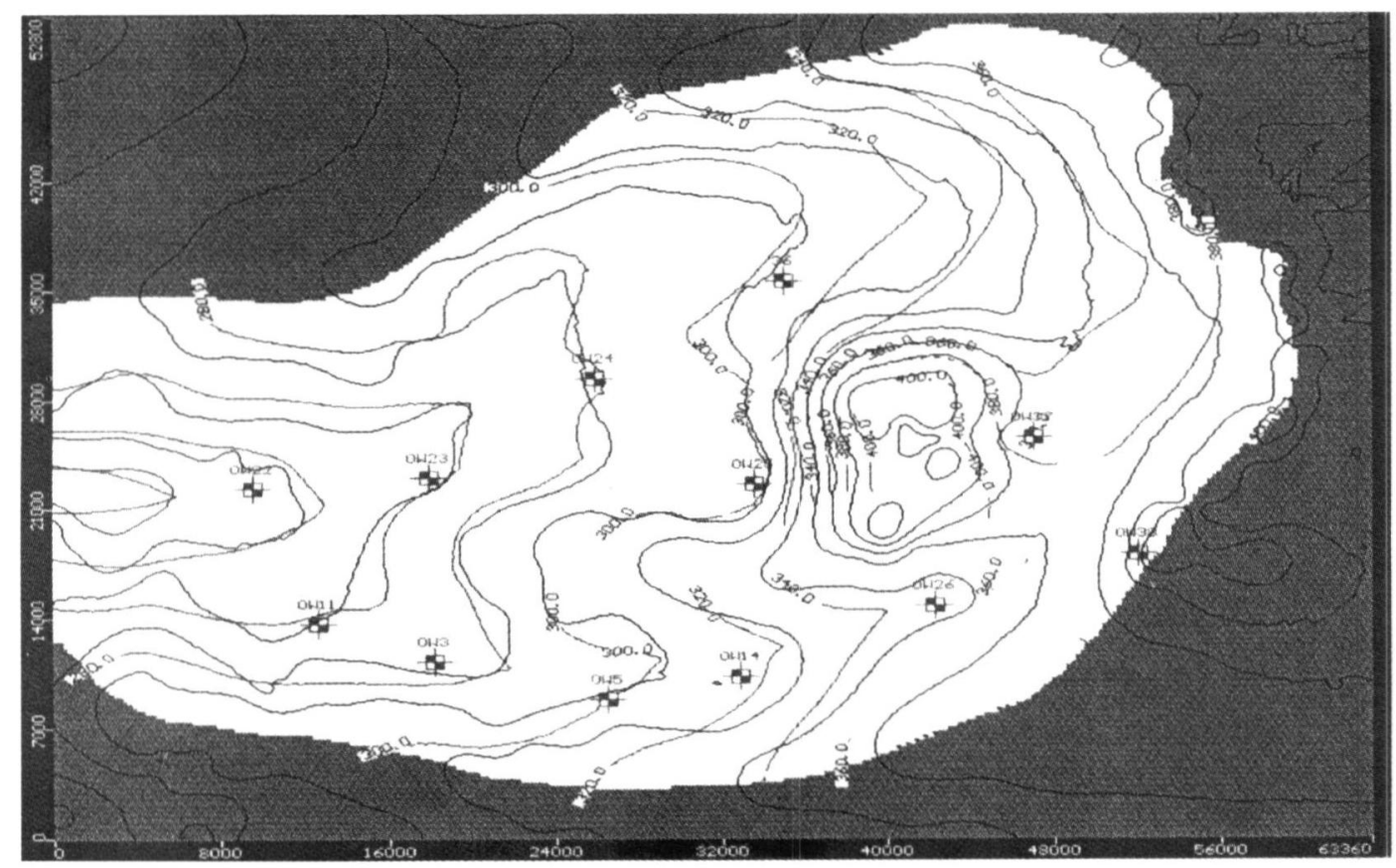

Figure 3 The comparison of observed and predicted head equipotential contours at the end of 1095 days.

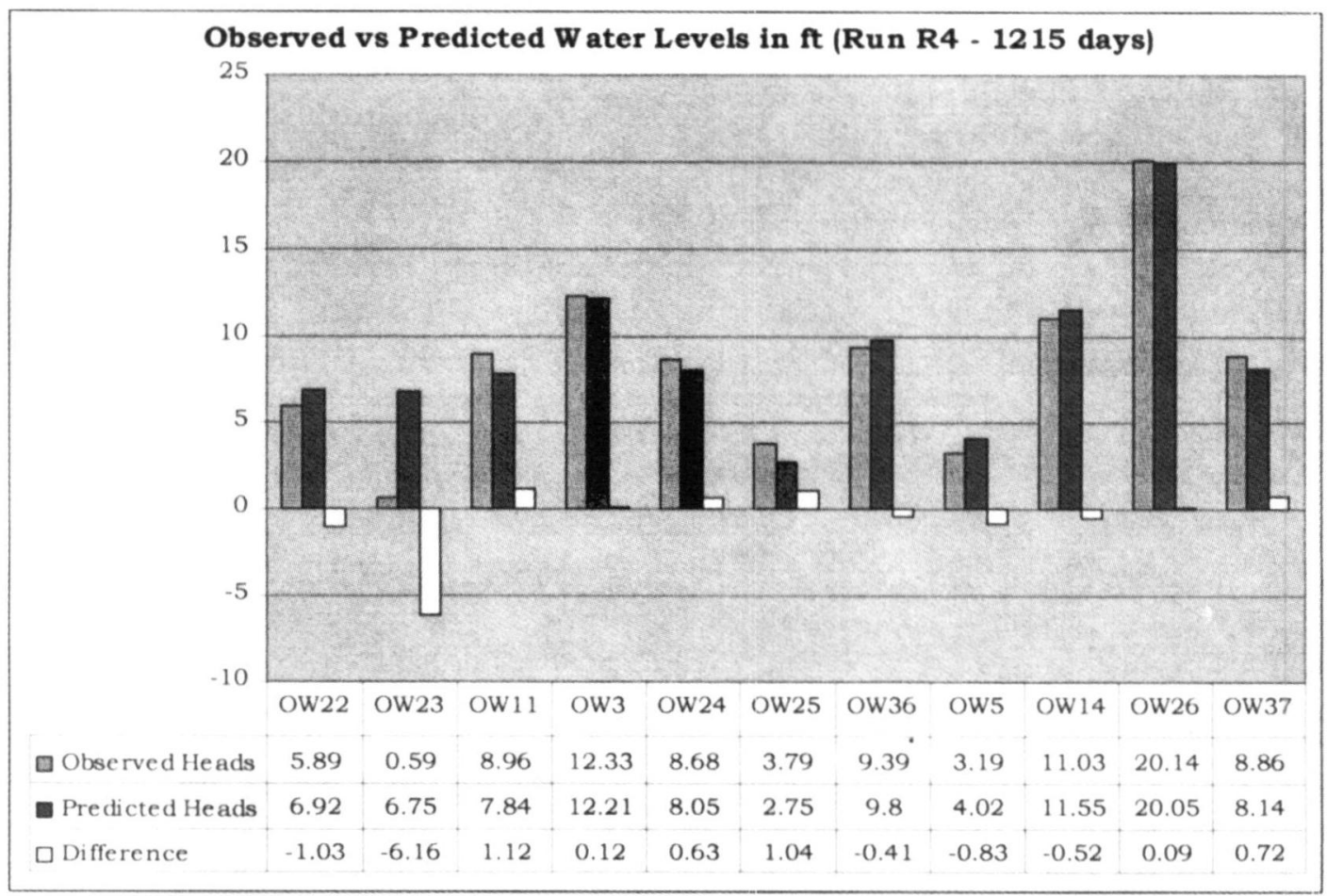

Figure 3A: Comparison between Model Run R3 E Model Run R4

coefficient were optimized while keeping the other inputs the same as R3. Figure 3 shows the comparison between the observed and predicted head equipotential counters of the domain at the end of 1095 days for the R4.

Though the actual values of C1 (Channel recharge coefficient) and C2 (Field recharge coefficient) differ from zone to zone and season to season, an average value of 0.53 for $\mathrm{C} 1$ and 0.7 for $\mathrm{C} 2$ showed satisfactory results in this simulation.

\subsection{R5 - Transient state flow simulation.}

The purpose of this simulation run is to examine the sensitivity of the river boundary condition in this study. Except for the exclusion of river boundary condition, all other initial and boundary conditions were the same as R4. The 
optimized values of data obtained from R3 \& R4 were used in this simulation.

The wells (OW3, OW36 and OW5) showed slightly higher predicted values in $\mathrm{R} 5$ run compared to R4 run. This implies that the stretches of river in this vicinity function as a sink and gain from the groundwater recharge. The wells (OW11, OW23, OW25 and OW26) showed slightly lower predicted values in $\mathrm{R} 5$ run compared to R4 run. This implies that the stretches of river in this vicinity function as a source and contributes to the groundwater table.

The two observation wells (OW22 and OW 14) showed slightly lower predicted values for the first two recharging periods and showed slightly higher predicted values for the third recharging period in $\mathrm{R} 5$ run compared to $\mathrm{R} 4$ run. This implies that the stretches of river in this vicinity function as a sink or source depending on the head difference between river and water table during the particular season.

In general, the changes in observed heads in the observation wells are small and this implies that the wells are less sensitive to the river boundary condition. This may be because the quantum of river recharge and river withdrawal are very small (less than 5\%) compared to the total recharge and total withdrawal.

\subsection{R6 - Transient state flow simulation}

Except for the inclusion of Subsurface Dams (refer Figure 4), the initial and boundary conditions were the same as R4. The optimized values of data obtained from $\mathrm{R} 3$ \& $\mathrm{R} 4$ were used in this simulation. The purpose of this simulation run is to examine the effect of Subsurface Dams in this study area.

In this simulation, the wells located closer to the downstream of a subsurface dam showed a fall in water level and the wells located closer to the upstream of a subsurface dam showed a rise in water level. The wells situated in the middle portion of a strip showed less sensitivity to Subsurface Dams. This information reveals that the sub surface dam helps to raise the water level in its upstream area at the expense of its downstream area. Further, the cumulative mass balance of run R6 showed that the difference in storage for the entire domain, caused by the sub surface dams, is very small.

\section{Water Balance}

After finding out the actual recharge into the aquifer and discharge from the aquifer of the study area during recharging and discharging periods, using the cumulative mass balance resulting from the model simulations, available

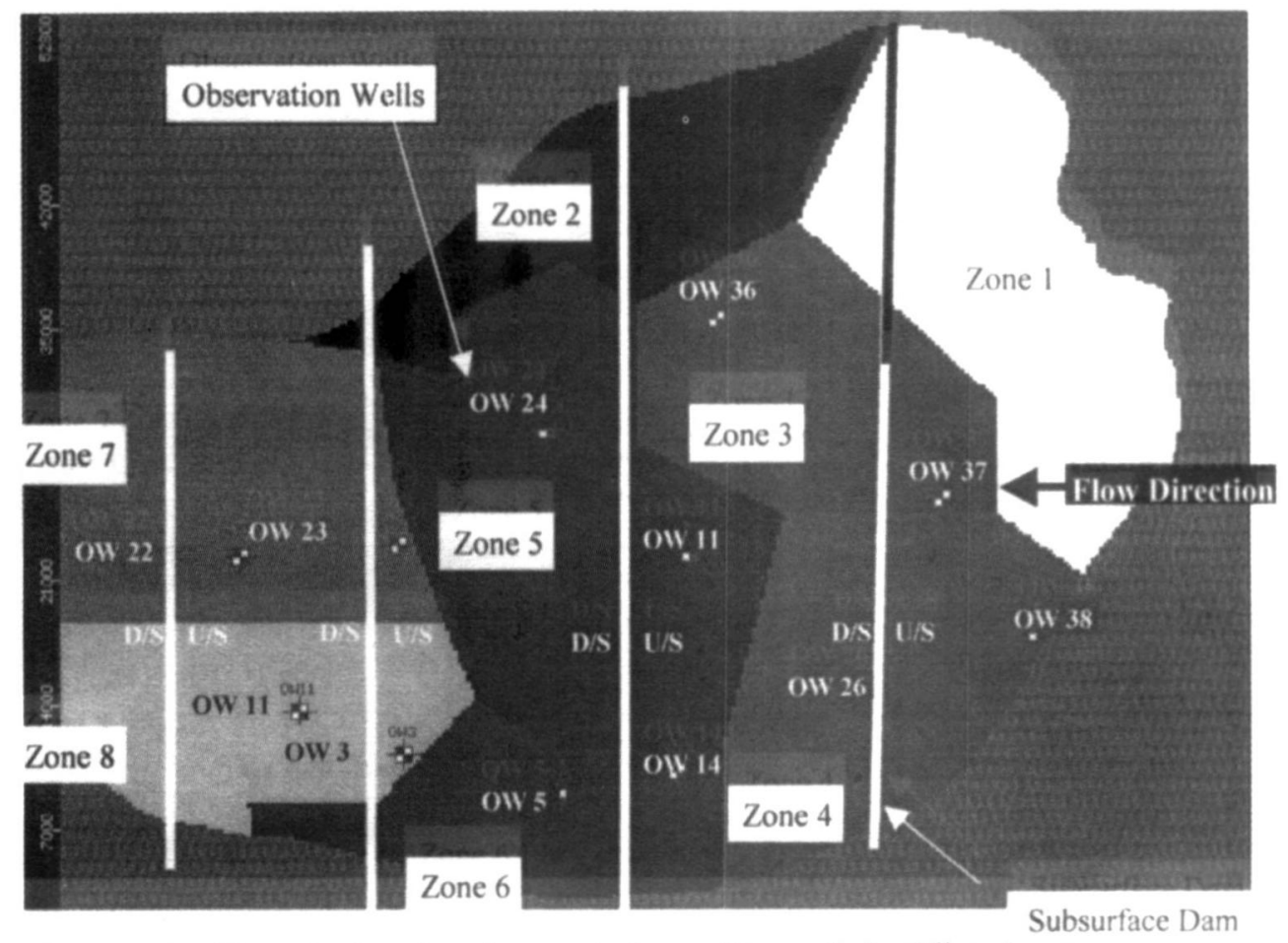

Figure 4 - Position of subsurface dams and observation wells in different zones 
data and the observed hydraulic head data, an attempt was made to close the overall water balance of the territory and to find out a sustainable Water Balance of the Territory for the optimum use of groundwater potential.

In an ideal situation, the total recharge to an aquifer shall be equal to the total withdrawal from the aquifer for a period of one year (covering recharging and a discharging periods), in order to optimize the use of groundwater potential in a sustainable manner. Such water balance for the study area, derived from the average values of 8 seasons is given in Table 2.

Table 2 - The Average Water Balance of the Study Area.

\begin{tabular}{|c|c|c|c|c|c|}
\hline & Components & Unit & $\begin{array}{l}\text { Surface Water } \\
\text { Balance }\end{array}$ & \multicolumn{2}{|c|}{$\begin{array}{c}\text { Aquifer Water } \\
\text { Balance }\end{array}$} \\
\hline $\begin{array}{l}1 \\
2 \\
3 \\
4 \\
5 \\
6 \\
7 \\
8 \\
9 \\
10 \\
11 \\
12\end{array}$ & $\begin{array}{l}\text { A) Recharging Period ( } 8 \text { months) } \\
\text { Rainfall } \\
\text { Evaporation } \\
\text { Final Soil Moisture Deficit } \\
\text { Surface runoff } \\
\text { Infiltration ( rain recharge) } \\
\text { Recharge from Channel Losses } \\
\text { Recharge from field Losses } \\
\text { Recharge from tank Losses } \\
\text { Pumping (Domestic) } \\
\text { Pumping (Agro) } \\
\text { River recharge } \\
\text { Apparent Recharge }\end{array}$ & $\begin{array}{l}\mathrm{mm} \\
\mathrm{mm} \\
\mathrm{mm} \\
\mathrm{mm} \\
\mathrm{mm} \\
\mathrm{mm} \\
\mathrm{mm} \\
\mathrm{mm} \\
\mathrm{mm} \\
\mathrm{mm} \\
\mathrm{mm} \\
\mathrm{mm}\end{array}$ & $\begin{array}{lr}+ & 1185.00 \\
- & 645.00 \\
- & 8.20 \\
- & 329.00 \\
- & 202.80\end{array}$ & $\begin{array}{l}+ \\
+ \\
+ \\
+ \\
- \\
- \\
+ \\
-\end{array}$ & $\begin{array}{r}202.80 \\
13.50 \\
13.30 \\
9.80 \\
12.60 \\
90.90 \\
1.30 \\
137.20 \\
\end{array}$ \\
\hline & Balance & $\mathrm{mm}$ & 0.00 & & 0.00 \\
\hline $\begin{array}{l}1 \\
2 \\
3 \\
4 \\
5 \\
6 \\
7 \\
8 \\
9 \\
10 \\
11 \\
12\end{array}$ & $\begin{array}{l}\text { B) Discharging Period ( } 4 \text { months) } \\
\text { Rainfall } \\
\text { Evaporation } \\
\text { Final Soil Moisture Deficit } \\
\text { Surface runoff } \\
\text { Infiltration (rain recharge) } \\
\text { Recharge from Channel Losses } \\
\text { Recharge from field Losses } \\
\text { Recharge from tank Losses } \\
\text { Pumping (Domestic) } \\
\text { Pumping (Agro) } \\
\text { Unaccounted recharge } \\
\text { Apparent Recharge }\end{array}$ & $\begin{array}{l}\mathrm{mm} \\
\mathrm{mm} \\
\mathrm{mm} \\
\mathrm{mm} \\
\mathrm{mm} \\
\mathrm{mm} \\
\mathrm{mm} \\
\mathrm{mm} \\
\mathrm{mm} \\
\mathrm{mm} \\
\mathrm{mm} \\
\mathrm{mm}\end{array}$ & $\begin{array}{r}232.00 \\
140.00 \\
25.30 \\
61.00 \\
5.70\end{array}$ & $\begin{array}{l}+ \\
+ \\
+ \\
+ \\
- \\
+ \\
+\end{array}$ & $\begin{array}{r}5.70 \\
5.90 \\
5.90 \\
1.80 \\
7.50 \\
149.70 \\
0.70 \\
137.2 \\
\end{array}$ \\
\hline & Balance & $\mathrm{mm}$ & 0.00 & & 0.00 \\
\hline $\begin{array}{l}1 \\
2 \\
3 \\
4 \\
5 \\
6 \\
7 \\
8 \\
9 \\
10 \\
11 \\
12\end{array}$ & $\begin{array}{l}\text { C) Year } \\
\text { Rainfall } \\
\text { Evaporation } \\
\text { Final Soil Moisture Deficit } \\
\text { Surface runoff } \\
\text { Infiltration ( rain recharge) } \\
\text { Recharge from Channel Losses } \\
\text { Recharge from field Losses } \\
\text { Recharge from tank Losses } \\
\text { Pumping (Domestic) } \\
\text { Pumping (Agro) } \\
\text { River recharge } \\
\text { Unaccounted Recharge }\end{array}$ & $\begin{array}{l}\mathrm{mm} \\
\mathrm{mm} \\
\mathrm{mm} \\
\mathrm{mm} \\
\mathrm{mm} \\
\mathrm{mm} \\
\mathrm{mm} \\
\mathrm{mm} \\
\mathrm{mm} \\
\mathrm{mm} \\
\mathrm{mm} \\
\mathrm{mm}\end{array}$ & $\begin{array}{rr}+ & 1417.00 \\
- & 785.00 \\
- & 33.50 \\
- & 390.00 \\
- & 208.50\end{array}$ & $\begin{array}{l}+ \\
+ \\
+ \\
+ \\
+ \\
+ \\
+ \\
+\end{array}$ & $\begin{array}{r}208.50 \\
19.40 \\
19.20 \\
11.60 \\
20.10 \\
240.60 \\
1.30 \\
0.70\end{array}$ \\
\hline & Balance & $\mathrm{mm}$ & 0.00 & & 0.00 \\
\hline
\end{tabular}


Table 3 - The Water Balance Comparison

\begin{tabular}{|c|c|c|c|c|c|c|c|c|c|c|}
\hline & \multicolumn{2}{|c|}{$\begin{array}{c}\text { According to } \\
\text { Average Water } \\
\text { Balance } \\
\end{array}$} & \multicolumn{2}{|c|}{$\begin{array}{l}\text { October } 98 \text { to } \\
\text { September } 99\end{array}$} & \multicolumn{2}{|c|}{$\begin{array}{l}\text { October } 99 \text { to } \\
\text { September } 00\end{array}$} & \multicolumn{2}{|c|}{$\begin{array}{l}\text { October } 00 \text { to } \\
\text { September } 01\end{array}$} & \multicolumn{2}{|c|}{$\begin{array}{l}\text { October } 01 \text { to } \\
\text { September } 02\end{array}$} \\
\hline & Value & $\%$ & Value & $\%$ & Value & $\%$ & Value & $\%$ & Value & $\%$ \\
\hline $\begin{array}{l}\text { Rainfall in } 106 \\
\text { cuft }\end{array}$ & 9,001 & ${ }^{*} 100$ & 9,894 & $* 110$ & 1,0938 & ${ }^{* 122}$ & 8,313 & *92 & 6,865 & ${ }^{* 76}$ \\
\hline $\begin{array}{l}\text { Recharge in } 106 \\
\text { cuft }\end{array}$ & 1,656 & $* \star 18$ & 1,977 & $* \star 20$ & 1,719 & $* * 16$ & 1,584 & **19 & 1,287 & *^19 \\
\hline $\begin{array}{l}\text { Withdrawal in } \\
106 \text { cuft }\end{array}$ & 1,656 & **18 & 2,039 & $\star \star 21$ & 1,705 & $* \star 16$ & 1,445 & **17 & 1,438 & $\star \star 21$ \\
\hline \multicolumn{3}{|c|}{$\begin{array}{l}\text { Change in Storage during the } \\
\text { year in } 106 \text { cuft }\end{array}$} & -62 & & 14 & & 140 & & -151 & \\
\hline
\end{tabular}

* (Rainfall Value of the year/Rainfall value according to average water balance) $\times 100$

** (Recharge Value or Withdrawal value of the year/Rainfall value of the year) $\times 100$

\section{Evaluation of Actual Water Balance}

Table 3 illustrates the comparison between the Ideal Water Balance derived from the average values of 8 seasons and the Actual Water Balance for four years from October 1999.

During October 1998 to September 1999, the rainfall received is $10 \%$ more than that of the average value and the \% of recharge is only $2 \%$ more compared to the average percentage. The $\%$ of withdrawal is $3 \%$ more than that of the average percentage. The groundwater potential was over exploited than its optimum level.

During October 1999 to September 2000, the rainfall received is $22 \%$ more than that of the average value and the $\%$ of recharge is $2 \%$ less compared to the average percentage. The $\%$ of withdrawal is $1 \%$ less than that of the average percentage. The groundwater potential was almost utilized to its optimum level.

During October 2000 to September 2001, the rainfall received is $8 \%$ less than that of the average value and the $\%$ of recharge is also $1 \%$ more compared to the average percentage. The $\%$ of withdrawal is $1 \%$ less than that of the average percentage. The groundwater potential was not utilized to its optimum level.

During October 2001 to September 2002, the rainfall received is $24 \%$ less than that of the average value and the \% of recharge is also $1 \%$ more compared to the average percentage. The $\%$ of withdrawal is $3 \%$ more than that of the average percentage. The groundwater potential was over extracted than its optimum level.
The above analysis shows that the groundwater withdrawal is not proportional to the recharge received during the year and this reveals that the groundwater is not managed in a sustainable manner in this region. If low rainfall is recorded continuously for two or more years, the groundwater situation will not only affect the agriculture but also will cause problems in meeting the domestic needs. This cautions the urgent need for a monitoring and regulating system to ensure the sustainability in groundwater management.

Further, it is noted that the \% of total recharge is not directly proportional to the rainfall. This is because the quantum of recharge not only depends on the magnitude of the rainfall, but also depends on its distribution. For example, if $35 \mathrm{~mm}$ of rainfall is recorded in an evenly distributed manner for a seven day period during which 5 $\mathrm{mm}$ daily evapotranspiration takes place, no recharge will occur. But if this $35 \mathrm{~mm}$ of rainfall is recorded in a day, $30 \mathrm{~mm}$ recharge will occur.

\section{Conclusions}

Based on the results of the studies the following conclusions can be made.

(1) Since the groundwater is not managed in a sustainable manner in this region, the problems related to groundwater are inevitable especially during low rainfall years. Therefore, action is required to regulate the groundwater usage and withdrawal especially in low rainfall years.

(2) The non-perennial river passing through this region causes a lower effect in the 
groundwater system. Some stretches of this river function as a source and contributes to the groundwater table. Some other stretches of this river function as a sink and withdraws from the groundwater table. But, volumes of recharge and withdrawal are almost equal and very small. Therefore, the net recharge or net withdrawal is almost negligible.

(3) The analysis with subsurface walls reveals that the wall boundary helps to raise the water level within a strip in the lower area at the expense of the upper area. But the effect is comparatively very low. The low hydraulic conductivity and low specific yield of this aquifer may be the reason for this less response. Anyhow, it can be concluded that the wall boundary condition certainly has an impact on the groundwater system and this has to be studied in detail in order to minimize the negative impact and utilize the merits of this condition.

\section{Acknowledgements}

The encouragement and guidance extended by Dr.S.P.Samarawickrama, Senior Lecturer attached to the Department of Civil Engineering, University of Moratuwa in this research is gratefully acknowledged.

\section{References}

1. Boonstra, J, and De-Ridder, N A, 1981. Numerical modeling of groundwater basins. 29 ILRI, Wageningen, ILRI Publication, 1981.

2. De Silva, C S, 1995. The use of agro wells for supplementary irrigation from Hard - rock aquifers of Sri Lanka. Ph.D Thesis, Silsoe College, Cranfield University, UK, 1995.

3. Grindley, J, 1967. The estimation of soil moisture deficits. Meteorol. Mag. 96, 97-108.

4. Grindley, J, 1969. The calculation of actual evaporation and soil moisture deficits over specified catchment areas. Meteorol. Off. Bracknell, Hydrol. Mem. No. 38, 3 pages.

5. Lerner, D, 1990. Techniques. International Contributions to Hydrogeology - Groundwater recharge Vol.8, 1990, 99-228.

6. Penman, H L, 1949. The dependence of transpiration on weather and soil conditions. J. Soil Sci. 1, 74-89.
7. Penman, $\mathrm{H} \mathrm{L}, 1950$. The water balance of the Stour catchment area. J. Inst. Water Eng. 4, 457469.

8. Ponrajah, A J P, 1984. Design of Irrigation headworks for small catahments, 2nd edition. Colombo, Irrigation Department, 1984.

9. Prudic, D E, 1988. Documentation of a computer program to simulate stream-aquifer relations using a modular, finite-difference, ground-water flow model. U.S.Geological Survey open file report, 1988, 729.

10. Reilly, T E and Harbaugh, A W, 1993. Simulation of cylindrical flow to a well using the U.S. Geological Survey modular finite - difference groundwater flow model. GROUND WATER Vol. 31, June 1993, 489-494.

11. Rushton, K R, and Ward, C, 1979. The estimation of groundwater recharge. Journal of Hydrology, $41,1979,345$ - 361 . 